\title{
Green Hypocrisy?: Environmental Attitudes and Residential Space Heating Expenditure
}

Laura Traynor

Ian Lange

Mirko Moro

Stirling Economics Discussion Paper 2012-12

May 2012

Online at

http://www.management.stir.ac.uk/research/economics/workingpapers 


\title{
Green Hypocrisy?: Environmental Attitudes and Residential Space Heating
} Expenditure

\author{
Laura Traynor \\ Division of Economics \\ University of Stirling \\ Stirling, FK94LA \\ lauratraynor@sky.com
}

\author{
Ian Lange \\ Division of Economics \\ University of Stirling \\ Stirling FK94LA \\ i.a.lange@stir.ac.uk \\ +44(0) 1786467276 \\ (Corresponding Author)
}

\author{
Mirko Moro \\ Division of Economics \\ University of Stirling \\ Stirling FK94LA \\ mirko.moro@stir.ac.uk
}

\begin{abstract}
In the UK, the largest proportion of household energy use is for space heating. Popular media make claims of a green hypocrisy: groups which have the strongest attitude towards the environment have the highest emissions. This study examines whether environmental attitudes and behaviours are associated with space heating energy use using data from the British Household Panel Survey. Results find that environmentally friendly attitudes generally do not lead to lower heating expenditures though environmentally friendly behaviours are associated with lower heating expenditure. Also, the effect of these attitudes and behaviours do not change as income increase.
\end{abstract}

JEL codes: Q40; Q50.

Keywords: green hypocrisy, heating expenditures, environmental attitudes, BHPS 


\section{Introduction}

Without a doubt, environmental awareness has been increasing in the last decades. This trend is reflected in the growth of a number of environmentally-friendly products (see e.g., Chen, 2011 and Hunt and Dorfman, 2008), from fluorescent bulbs to organic food (see e.g., Torjusen et al. 2001). As the example on fluorescent bulbs shows, environmental consciousness should translate into socially better decisions and energy saving behaviours. Surveys shows that wealth and status are often associated with green knowledge and general concern towards environmental quality (Diamantopoulos et al., 2003). However, there is also an idea deeply rooted in public discourses that environmental awareness translates itself more into slogans than actions. A green discourse is not reflected by actual green actions, or at best, these actions are very marginal. A Google search of the terms such as "Green hypocrisy" or "Environmental hypocrisy" returns 31,000 pages, more than 9,000 of which from last year (Google accessed on 15 May 2012), which deal with conflicts between the lifestyles of (sometimes very wealthy and famous) members of green parties or groups advocating energy savings and carbon neutral policies while leaving large footprints behind.

This begs the question as to whether environmental attitudes and behaviours are linked with actions. In this paper, we will focus on UK household energy heating expenditures. Governments around the world are introducing a number of energy use and emissions goals in order to improve energy security and reduce carbon emissions. Policies aimed at the household sector focus on improving the energy efficiency or reducing their energy use. Figure 1 shows the break down of residential energy consumption in UK into its four main component parts: space heating, water heating, lighting and appliances, and cooking. Accounting for $61 \%$ of domestic energy use, space heating requires by far the greatest demand for energy in the home. Thus, understanding the determinants of space heating demand would open up substantial possibilities for policy development to help reduce energy demand by households. This would aid in the attainment of energy efficiency and carbon emission reduction targets set by government. Holding everything else constant, individuals with strong environmental attitudes and behaviours should spend less on space heating per room. However, if green hypocrisy is pervasive, there should be no relationship between heating expenditure and attitudes, especially considering that heating expenditure are difficult to be monitored and scrutinized, and so more easily prone to "deceitful" behaviour. 
Previous econometric studies on the determinants of household space heating had focused on building and socio-economic characteristics of the households, while the field of psychology investigates the impact of holding environmental beliefs. This study attempts to combine the two topics, and proposes the hypothesis that environmental attitudes are also determinants of residential space heating expenditures. Van den Bergh (2008) remarks that there are few econometric studies which attempt to link environmental attitudes and household energy use. This analysis attempts to fill the gap in the existing literature by using data from the British Household Panel Survey (BHPS). The most recent wave of the BHPS, wave 18, contains data relating to environmental issues as well as the standard questions relating to household energy expenditure.

\section{Residential energy demand}

Residential energy demand has been a subject of research for many years. Hartman (1979) reviewed previous literature on attempts to model this demand. Houthakker (1951) is the earliest, which sought to model household expenditure on electricity as a function of income and as a function of household total spending. Of course, patterns of residential energy demand will have changed significantly since Houhakker's calculations, with increased appliance ownership and usage as well as higher standards of living. A key difference in terms of space heating is the proliferation of central heating (DECC, 2011b). More recent models of space heating demand will have taken this technology into account. Dubin and McFadden (1984) modelled residential electricity demand in the United States, including demand for both space and water heating and appliance use. Nesbakken (2001) extends Dubin and McFadden (1984) to include households that utilize more than one fuel in their energy use. They find that building age, age of household and building size are all important

Leth-Petersen and Togeby (2001) examined apartment blocks, the whole apartment block and not the individual households within, to find that block age, fuel type, and year of most recent remodelling are the most important determinants of energy use. Rehdanz (2007) examines the determinants of residential space heating expenditures per square meter in Germany. One of the key distinctions made in this paper is the differentiation between homeowners and renters. This is an expansion on previous work undertaken by Schuler et al. (2000) for West Germany only. Meier and Rehdanz (2010) replicate the German analyses for the UK using the BHPS, however the BHPS does not have detailed information on the building size thus heating expenditure per room is used. Meier and Rehdanz (2010) find that heating expenditures for 
homeowners was higher than for renters, the opposite of what was found in Rehdanz (2007). Abrahamse and Steg (2009) examine the factors that determine energy use versus energy saving. They find that attitudes are important for energy saving actions but less important for energy use.

However all of these analyses exclude any discussion of environmental attitudes in determining energy use. In a review of the evidence of determinants of residential energy use, Van den Bergh (2008) states that most analyses relate household space heating use with physical and socio-economic attributes only and few have linked space heating with environmental attitudes. Further, much of the existing research into environmental attitudes relating to energy use comes from the field of psychology, and has rarely been linked to econometric analysis. Two analyses, Clark et al (2003) and Kotchen and Moore (2007), have linked environmental attitudes to green electricity purchases, electricity generated by renewable resources. Di Maria et al. (2010) examine the determinants of uptake of compact fluorescent light bulbs (CFLs) in Ireland using socio-economic variables and environmental attitudes. They find that environmental attitudes and education levels are strong determinants of installation of CFL. Specific to residential heating expenditure example of a psychological study is Becker et al (1981) found that the key explanatory variable behind household energy use was thermal comfort.

\section{Data \& Methods}

To examine environmental attitudes and heating expenditures in the UK, BHPS data will be utilized in this analysis. The BHPS samples over 5000 households per year on a multitude of topics including income, expenditure and housing. The contents of the survey have changed over the years, with new questions added and some existing questions being altered or removed. The latest release of BHPS data, wave 18, adds questions relating to environmental attitudes. The analysis here is cross sectional due to the lack of environmental attitudes questions asked in previous versions of the BHPS. The data used here was collected between September 2008 and April 2009, sampling 8,144 households in the United Kingdom. This is comprised of 3,976 responses from households in England, 1,427 households in Wales, 1,497 households in Scotland, and 1,244 households in Northern Ireland.

The dependent variable here is the annual heating expenditure per room, similar to Meier and Rehdanz (2010). This was calculated by taking the household expenditure on the fuel type 
used for heating, and dividing it by the number of rooms to approximate the effects of different sizes of homes. This approximation was used because the BHPS does not contain information regarding the specific size of the dwelling. Table 1 shows the descriptive statistics of variables used in this analysis.

The independent variables are organized into three groups: building attributes, household characteristics, and environmental attitudes. The first building attribute variable is the fuel used for space heating: Electricity, Gas and Oil. ${ }^{1}$ These are dummy variables where the value is one if the fuel type used is the fuel named, and zero if otherwise. The majority of homes (71\%) use gas as their heating fuel, except in Northern Ireland where 76\% use oil for heating. In terms of cost, electric heating is usually more expensive than gas, and oil heating is usually more expensive than electricity (DECC, 2011a). However, electricity expenditure will also include the cost of running household appliances as well as the cost of space heating and water heating, and thus is likely to be shown to have higher expenditures than the other heating types.

Variables are created to account for different levels of exposure to external air for the building. A detached house would be assumed to have $100 \%$ of its boundary walls exposed to the air surrounding the property (excluding non-heated additions to the property such as a garage), whereas a semi-detached house, end of terraced house, terraced house, or a flat will share walls with a neighbouring property or properties. This will reduce the amount of heat lost to the air surrounding the property and may result in heat gains from the neighbouring properties. Thus heating expenditures for detached properties would be expected to be higher than other types of housing, even if the size of the property is taken into account. Dummy variables are created for detached properties, semi-detached properties, end of terrace houses, mid-terraced houses, flats in buildings with less than 10 separate properties, and flats in buildings with more than 10 separate properties. The variables carry the value of one if they are the named type of housing and zero if otherwise. Buildings that are thermally inefficient may show signs of problems such as condensation, damp, or rot in wooden surfaces such as window frames or floorboards. These variables serve as a measure of thermal inefficiency that could otherwise have been demonstrated by building age, which is not included in the

\footnotetext{
${ }^{1}$ Other fuels, for example solid fuels such as wood, are not separately accounted for due to the small number of households using this as their primary heating fuel. However, only $4.84 \%$ of households in the sample do not have central heating, therefore the reduction in observations is relatively small.
} 
BHPS. Dummy variables are created for homes with condensation, leaky roofs, rotten window frames or floors, and damp respectively. They take the value of one if the accommodation has the named problem and is zero otherwise.

The BHPS also lacks information relating to the precise size of dwellings. Number of rooms in the property is used to proxy for size. More rooms is expected to be negatively correlated with heating expenditure per room as non-heated rooms adjacent to heated rooms will need to be heated less to achieve a comfortable temperature.

The characteristics of the people in the household will also affect heating expenditures. Several studies mentioned earlier found that the tenure type of the property, i.e. whether the property was owned by the residents or rented, is a determinant of heating expenditure. The expected impact of tenure on heating expenditures is ambiguous. On the one hand, expenditures are expected to be higher for owners than renters as a consequence of a wealth effect. On the other hand, in terms of thermal efficiency, it may be that owners are able to makes changes to their property that renters cannot or that the principal-agent problem, whereby the owner is not able to appropriate the benefits of investment in improved efficiency, limits the potential to improve thermal efficiency. Annual household income, in $£$, is expected to be positively correlated with heating expenditure. Larger households are expected to have higher heating expenditure. A similar effect is expected from the number of children living in a household. As well as requiring a higher temperature in the home (WHO, 1987), more rooms are likely to be in use at once, and thus heating expenditures is expected to be positively correlated with number of children in the household. Other types of vulnerable people will also require higher heating levels to maintain a healthy home environment, such as the elderly. Age is expected to follow a parabolic relationship to heating expenditures, increasing up to retirement age then declining. To capture this effect two variables relating to age were used: average age of adult residents and average age squared.

The average level of education in the household could be related to heating expenditures. In our econometric models we include the number of members with a degree, including teaching qualifications, nursing qualifications, and other higher qualifications. The employment status of the adults in the household is likely to be important. The number of individuals in a household listed as not in employment is expected to have an ambiguous relationship with 
heating expenditure. ${ }^{2}$ It could be that heating expenditures are higher due to being in the property more often or it could be that the uncertain income causes households to reduce thermal comfort. A variable is created to control for whether the household has installed solar water heating. This would be expected to reduce the expenditure for the fuel used for space heating as it is likely that the same fuel is used for both space and water heating. The solar heating variable takes the value of one if the dwelling has solar water heating installed and is zero otherwise. Becker et al (1981) stated that thermal comfort as key variable to heating use. The difficulty with this conclusion for econometric analysis is how to quantify thermal comfort. Respondents are asked whether they keep their house adequately warm; a dummy variable taking the value of one if the respondent indicated that they keep their home adequately warm and zero otherwise. Significant differences between the individual regions of the UK could alter heating expenditure, thus they are controlled for with region dummy variables.

There is one question in the BHPS that can be considered a behaviour rather than an attitude. The psychology literature suggests that questions related to specific behaviours are expected to be reflected better in actions than general attitudes (Ajzen \& Fishbein, 1980; Kollmuss \& Agyeman, 2002). It asks how often the respondent puts on more clothes when they feel cold rather than turn the heating on or turning it up. This question is answered based on a Likert scale. The add layers variable is translated so that a higher score implies a more environmentally friendly behaviour. This variable is parameterized by taking either the average response of all members of the household, the natural log of the average response, and a dummy variable taking the value of one if anyone in the household answered in the top two scales. This is behavioural variable is expected to be negatively correlated to heating expenditures.

$=$

There are a number of environmental attitude variables in the BHPS that are used to determine whether they are correlated with heating expenditure. Each attitude variable is converted so that a higher score implies a more environmentally friendly attitude, thus the coefficients on the environmental attitudes variables are expected to be negative. The first environmental attitude variable is whether the respondents believe that the UK will be affected by climate change in the next 30 years. The question was asked as a dichotomous

\footnotetext{
${ }^{2}$ Separating the "Not in Employment" variable into groups like retired and job status as "unemployed" was found to be not significant in the analysis.
} 
yes/no question in the individual respondent questionnaire, thus if a respondent said "yes" their answer is given the value of one and "no" answers are given a value of zero. For the UK affected by climate change variable, two versions are used in the analysis: the average response of residents in the household and a dummy variable equal to one if any member of the household said "yes". There are four environmental attitude questions which are based on a Likert scale and the variables are transformed in the same way the add layers variable is. The second environmental attitude variable is whether consideration is given by households to whether their actions are influenced by carbon dioxide $\left(\mathrm{CO}_{2}\right)$. The respondents are asked how frequently their behaviour is affected by the need to reduce carbon emissions. The third environmental attitudes question is whether individual respondents agreed with the statement that "the environment was a low priority compared to a lot of other things in their life. Similarly, a fourth environmental attitudes variable is whether the respondent believes that "it takes too much time and effort" to do things that are environmentally friendly. The fifth and final environmental attitudes variable asks if the respondent is environmentally friendly in most things they do. Table 2 provides the correlation between these six variables. All questions are positively correlated with not too much effort to be environmentally friendly and the environment priority variables being strongly correlated. ${ }^{3}$ The other correlations are similar to those found in Di Maria et al (2010).

The variables discussed are used in a regression to satisfy the following function of heating expenditures, modified from Meier and Rehdanz (2010):

$$
E_{i}=\alpha+\beta_{F} F_{i}+\beta_{H} H_{i}+\beta_{S} S_{i}+\beta_{R} R_{i}+\beta_{A} A_{i}+\beta_{B} B_{i}+\varepsilon_{i}
$$

in which:

$E_{i}=$ natural log of heating expenditure per room of household $i$,

$F_{i}=$ type of fuel used for space heating,

$H_{i}=$ home attributes,

$S_{i}=$ household characteristics,

$R_{i}=$ regional variables,

$A_{i}=$ environmental attitudes,

$B_{i}=$ environmental behaviour,

$\varepsilon_{i}=$ error term.

\footnotetext{
${ }^{3}$ Variance Inflation Factors confirm that multicolinearity is not a problem. Results are available from the authors
} by request. 
As this is a static model featuring data for just one year, features relating to time have been excluded from this formula. In order to investigate the joint impact of income and environmental questions on heating expenditures, model (1) will be modified to add an interaction between the income and environmental question variables.

\section{Results}

Results of the estimation of Equation 1 can be found in Table 3. Each regression contains 6052 observations and uses a heteroskedasticity-corrected region clustered standard error. All regressions in Table 3 have the natural logarithm of space heating fuel expenditures per room as the dependent variable. ${ }^{4}$ The specification of the environmental questions are the natural $\log$ of the average score, dummy variable for above a threshold, and the average score in Columns 1,2, and 3, respectively. The results are consistent for the building attributes and household characteristic variables across all models. Expenditure on the fuel used for heating was lowest in homes heated with gas fuelled central heating, then oil, and finally electricity. The coefficient on the logarithm of the number of rooms in the property was negative and significant at the $1 \%$ level. In other words, as the number of rooms increases, the heating expenditures per room decrease. All regressions show the owner variable to be positive, indicating that owners have higher heating expenditures than renters. To compare with work undertaken by Meier and Rehdanz (2010), additional regressions were run separately for owners and renters. However, differentiating between these two cases had little impact on the significance of the environmental attitude and behaviour variables.

Income is positively and statistically associated with heating expenditure with a coefficient less than 1. This would imply that space heating is a normal good. Age and Age Squared are significantly associated with heating expenditure in all regressions. Age and Age Squared are positive and negative respectively, indicating a parabolic relationship between fuel expenditures and age, as expenditures increase up to a certain age and then decline as incomes contract. This is consistent with the findings of previous authors. In regards to education levels, there is not a consistent relationship with heating expenditures. One of the models finds a positive statistical association while the others do not.

\footnotetext{
${ }^{4}$ The level of space heating fuel expenditure is also utilized as the dependent variable in regressions not shown here but available from the authors by request. Results are consistent with those shows in Table 4.
} 
As expected, the environmental behaviour variable, whether the household wears extra layers rather than turning the heating up when cold, is most consistently associated with a lower heating expenditure. A 1 unit increase in the average response to this question is associated with an $11 \%$ decrease in heating expenditure. Only one of the environmental attitude variables is consistently statistically associated with lower heating expenditure. Whether the household feels that it does not take time to be environmental is consistently associated with lower heating expenditures and has a similar magnitude to that of whether the household wears extra layers. Households that consider the carbon impact of their behaviour is negatively associated with heating expenditure in two of the three specifications. The other three environmental attitude variables are generally not statistically significant in the models and one specification finds that household who are environmentally friendly in what they do have statistically higher expenditure.

The regressions discussed above have shown that environmental behaviour, wearing an extra layer at home, and to some extent, environmental attitudes matter in the adoption of a ecofriendly actions. However, this does not test for evidence of a more specific green hypocrisy, a "direct link between wealth and willingness to embrace a green agenda" (BBC News ${ }^{5}$ ). Richer people, while promoting green behaviours, may contribute more to pollution and carbon emissions more, as a consequence of their lifestyle. The above analysis have shown that income is positively associated with heating expenditures, but does not reveal the more complex nature of the relationship between income, attitudes and green behaviour.

Our data enable us to test this relationship directly by adding interactions between income and environmental attitudes to our regressions. Two interaction specifications are used: $(a)$ linear income interacted with the dummy environmental question variables and $(b)$ a top $25 \%$ income dummy interacted with the natural $\log$ of the environmental question variables. If the green hypothesis were true, we should expect some (or all) interaction terms to be $(a)$ statistically significantly different from zero and $(b)$ of a positive sign. A positive sign would suggest that heating expenditures increase as income increases. Table 5 shows that none of the interaction terms between income and each of the environmental attributes are statistically significant on their own or when a joint test of significance is used. This set of regressions clearly rejects the hypothesis of a green hypocrisy.

\footnotetext{
${ }^{5}$ http://news.bbc.co.uk/1/hi/uk_politics/8393081.stm.
} 


\section{Conclusion}

The main aim of this study is to determine whether environmental attitudes and behaviours of household have any bearing on their space heating expenditures in the United Kingdom. The regression analysis undertaken suggests that this is in some ways true; claiming concerns towards the environment translates into energy saving-type of behaviour, or, on average, there is no evidence of green hypocrisy. About half of the environmental attitudes variables were statistically significant and the environmental behaviour variable is statistically significant. One of the key findings was that households who more frequently choose to wear extra layers rather than turn the heating up have lower heating expenditures than those who do this less frequently. Some of the regressions also stated that households who consider the carbon impact of their behaviour also had lower heating expenditures. Many of the building characteristics, type of heating fuel used, and socio-economic characteristics of the household are statistically associated with heating expenditure.

Having found that income is positively associated with expenditure, we investigated the idea that richer households with stronger attitudes towards environmental issues do not behave accordingly, a more specific type of green hypocrisy. When analysing the sign and statistical significance of interaction terms between income and each of the eco-friendly attitudes we do not find differences in the attitudes across income groups.

Overall it seems that while many of the people surveyed hold some degree of environmentally friendly beliefs, it is only the people who actively apply their beliefs to their lifestyle that have lower heating expenditures. The policy implications of this may mean that educational programmes designed to promote environmental issues, such as climate change, may not be sufficient to bring about behavioural change regarding household space heating. Programmes would perhaps need to incorporate ways to encourage people to link these environmental issues to their own behaviour and energy use patterns. 


\section{References}

Abrahamse, W. and Steg, L. (2009). How do socio-demographic and psychological factors relate to households' direct and indirect energy use and savings?, Journal of Economic Psychology, 30(5), 711-720

Ajzen, I. \& Fishbein, M. (1980) Understanding Attitudes and Predicting Social Behavior. Englewood Cliffs, NJ: Prentice Hall.

Baker, P., Blundell, R., and Micklewright, J. (1989). Modelling Household Energy Expenditures Using Micro-data. Economic Journal, 99(397), 720-38.

Becker, L. J., Seligman, C., Fazio, R. H., and Darley, J. M. (1981). Relating attitudes to residential energy use. Environment and Behavior, 13(5), 590-609.

Chen, C. (2001). Design for the Environment: A Quality-Based Model for Green Product Development. Management Science, 47(2), 250-263

Clark, C.F., Kotchen, M.J., Moore, M.R., (2003). Internal and external influences on proenvironmental behavior: participation in a green electricity program. Journal of Environmental Psychology 23, 237-246.

DECC, Department of Energy and Climate Change (2011a), UK Energy In Brief 2011

DECC, Department of Energy and Climate Change (2011b), Domestic Data Tables, Energy Consumption in the United Kingdom: 2011

DECC, Department of Energy and Climate Change (2011c), Annual Report on Fuel Poverty Statistics 2011

Di Maria, C. Ferreira, S., and Lazarova, E. (2010). Shedding Light on the Light Bulb Puzzle: The Role of Attitudes and Perceptions in the Adoption of Energy Efficient Light Bulbs, Scottish Journal of Political Economy, 57(1), 48-67.

Dubin, J.A. and McFadden, D.L. (1984). An Econometric Analysis of Residential Electric Appliance Holdings and Consumption. Econometrica, 52(2), 345-362. 
Hartman, R.S. (1979) Frontiers in energy demand modelling, Annual Review of Energy, 4, 433-466

Houthakker, H. S. (1951) Some Calculations on Electricity Consumption in Great Britain, Journal of the Royal Statistical Society. Series A (General) 114(3), 359-371

Hunt, N., \& Dorfman, B. (2009, 28 January). How Green is My Wallet? Organic Food Growth Slows. Reuters. Retrieved from http://www.reuters.com/article/2009/01/28/usfinancial-food-organic-idUSTRE50R01C20090128.

Kollmuss, A. \& Agyeman, J. (2002) Mind the Gap: Why do people act environmentally and what are the barriers to pro-environmental behavior?, Environmental Education Research, 8(3), 239-260.

Kotchen, M. and M. Moore. (2007) Private Provision of Environmental Public Goods: Household Participation in Green Electricity Programs, Journal of Environmental Economics and Management 53(1), 1-16.

Leth-Petersen, S. and Togeby, M. (2001). Demand for Space Heating in Apartment Blocks: Measuring Effects of Policy Measures Aiming at Reducing Energy Consumption. Energy Economics, 23(4), 387-403.

McFall, S. L. (2010). Understanding Society - The UK Household Longitudinal Study, Interim Release of Wave 1, Year 1 Data, User Manual. Colchester: University of Essex Meier, H. and Rehdanz, K. (2010). Determinants of Residential Space Heating Expenditures in Great Britain. Energy Economics, 32(5), 949-959.

Nesbakken, R. (2001). Energy Consumption for Space Heating: A DiscreteContinuous Approach. Scandinavian Journal of Economics, 103(1), 165-184.

Torjusen, H., Lieblein, G., Wandel, M., \& Francis, C. A. (2001). Food System Orientiation and Quality Perception Among Consumers and Producers of Organic Food in Hedmark County, Norway. Food Quality and Preference, 12, 207-216 
Schuler, A., Weber, C., Fahl, U. (2000) Energy consumption for space heating of WestGerman households: empirical evidence, scenario projections and policy implications. Energy Policy, 28, 877-894.

Rehdanz, K. (2007). Determinants of Residential Space Heating Expenditures in Germany. Energy Economics, 29(2), 167-182.

Van den Bergh, J. C. J. M. (2008) Environmental regulation of households: An empirical review of economics and psychological factors. Ecological Economics. 66. 559-574

WHO, World Health Organisation (1987) Health impact of low indoor temperatures. WHO Environmental Health Series No 16. Copenhagen, WHO Regional Office for Europe. 
Figure 1: Domestic Energy Use by type, 2009

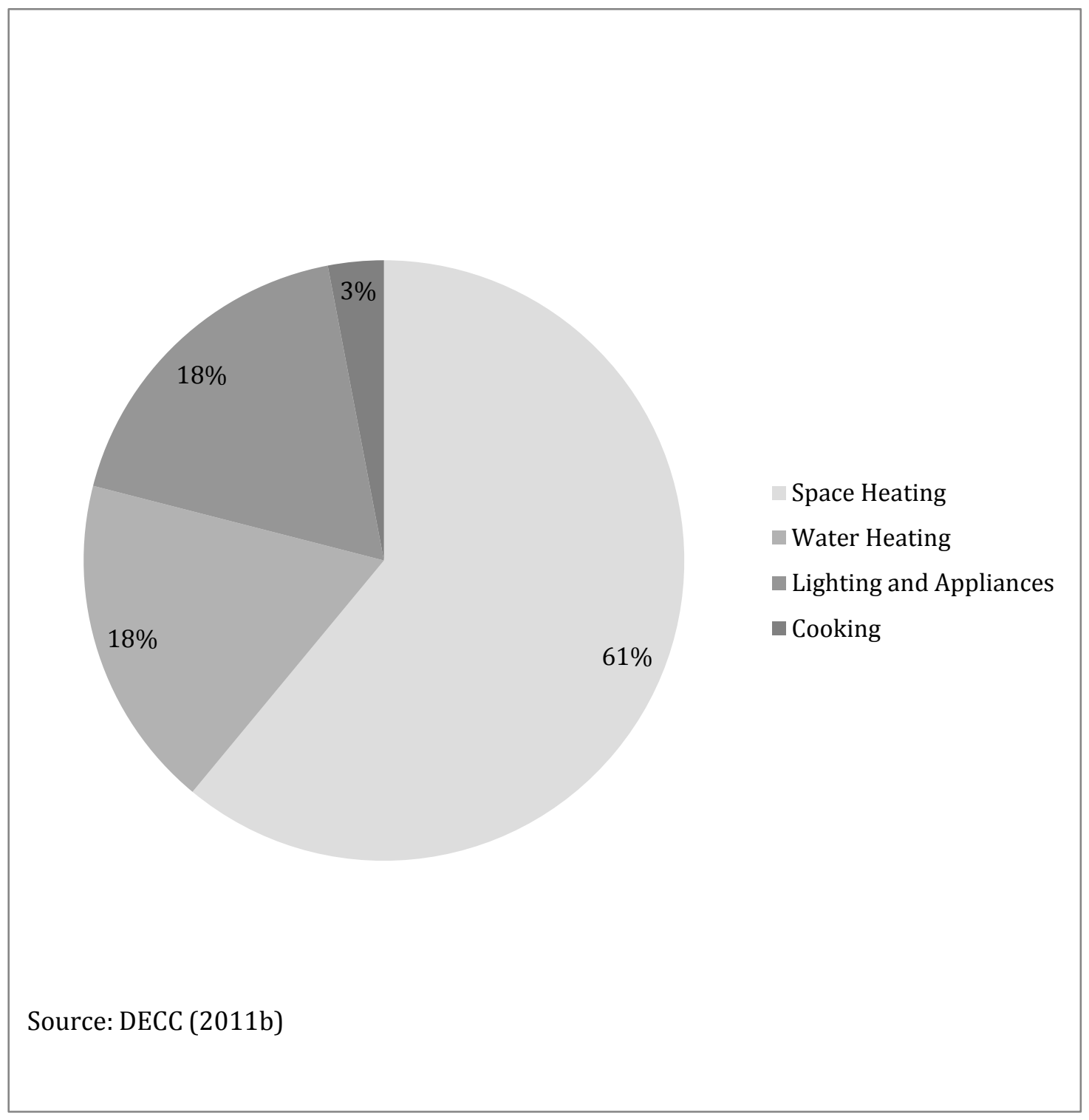


Table 1: Summary Statistics

\begin{tabular}{|c|c|c|c|}
\hline Variable name & Brief description & Mean & S.D. \\
\hline Space Heating & & 160.6 & 96.41 \\
\hline \multirow{2}{*}{\multicolumn{4}{|c|}{$\begin{array}{l}\text { Expenditure per Room } \\
\text { (f) }\end{array}$}} \\
\hline & & & \\
\hline \multicolumn{4}{|l|}{ Building Attributes } \\
\hline Electricity (ref. cat.) & $\begin{array}{l}\text { Dummy taking the value of } 1 \text { if electric } \\
\text { heating used }\end{array}$ & 0.08 & 0.25 \\
\hline Gas & $\begin{array}{l}\text { Dummy taking the value of } 1 \text { if gas heating is } \\
\text { used }\end{array}$ & 0.71 & 0.45 \\
\hline Oil & $\begin{array}{l}\text { Dummy taking tha value of } 1 \text { if oil heating is } \\
\text { used }\end{array}$ & 0.18 & 0.39 \\
\hline $\begin{array}{l}\text { Detached House (ref. } \\
\text { cat.) }\end{array}$ & $\begin{array}{l}\text { Dummy taking the value of } 1 \text { if house is } \\
\text { detached }\end{array}$ & 0.27 & 0.44 \\
\hline Semi-Detached House & $\begin{array}{l}\text { Dummy taking the value of } 1 \text { if house is semi- } \\
\text { detached }\end{array}$ & 0.31 & 0.46 \\
\hline End of Terrace House & $\begin{array}{l}\text { Dummy taking the value of } 1 \text { if house is end- } \\
\text { of-terrace }\end{array}$ & 0.08 & 0.27 \\
\hline Terrace House & $\begin{array}{l}\text { Dummy taking the value of } 1 \text { if house is } \\
\text { terrace }\end{array}$ & 0.18 & 0.37 \\
\hline Flat $w /<10$ properties & $\begin{array}{l}\text { Dummy taking the value of } 1 \text { if household } \\
\text { live in flat in buildings with less than } 10 \\
\text { properties }\end{array}$ & 0.11 & 0.3 \\
\hline Flat w/>10 properties & $\begin{array}{l}\text { Dummy taking the value of } 1 \text { if household } \\
\text { live in flat in buildings with more than } 10 \\
\text { properties }\end{array}$ & 0.04 & 0.19 \\
\hline Condensation Problem & $\begin{array}{l}\text { Dummy taking the value of } 1 \text { if house has } \\
\text { condensation problems }\end{array}$ & 0.08 & 0.28 \\
\hline Damp Problem & $\begin{array}{l}\text { Dummy taking the value of } 1 \text { if house has } \\
\text { damp problem }\end{array}$ & 0.07 & 0.25 \\
\hline Rot Problem & $\begin{array}{l}\text { Dummy taking the value of } 1 \text { if house has rot } \\
\text { problem }\end{array}$ & 0.04 & 0.18 \\
\hline Leaking Roof & $\begin{array}{l}\text { Dummy taking the value of } 1 \text { if house has } \\
\text { leaking roof }\end{array}$ & 0.03 & 0.18 \\
\hline Number of Rooms & Number of rooms in house & 4.61 & 1.68 \\
\hline \multicolumn{4}{|c|}{ Characteristic of Household } \\
\hline Owner Occupied & $\begin{array}{l}\text { Dummy taking the value of } 1 \text { if house is } \\
\text { owner occupied }\end{array}$ & 0.72 & 0.44 \\
\hline Income $(£)$ & Annual household income & 32350 & 24718 \\
\hline Household Size & Number of household members & 2.45 & 1.33 \\
\hline Number of Children & Number of children in the household & 0.5 & 0.91 \\
\hline Not Employed & $\begin{array}{l}\text { Number of household members that are not } \\
\text { employed }\end{array}$ & 1.29 & 1.16 \\
\hline Age & $\begin{array}{l}\text { Average age of adult member of the } \\
\text { household }\end{array}$ & 49.33 & 18.16 \\
\hline Degree & $\begin{array}{l}\text { Number of household member holding a } \\
\text { degree and professional degrees (e.g., } \\
\text { teaching, nursing and other higher }\end{array}$ & 0.45 & 0.43 \\
\hline
\end{tabular}


qualifications)

Solar Water Heater

Keep House Warm

Environmental behavior

Add Layers

Environmental attitudes

UK Affected by CC

Influenced by $\mathrm{CO} 2$

Environment Priority

Time to be

Environmental

Environment Friendly

Region dummies

Inner London

Outer London

R. of South East

South West

East Anglia

East Midlands

West Midlands

Conurbation

R. of West Midlands

Greater Manchester

Merseyside

R. of North West

South Yorkshire

West Yorkshire
Dummy taking the value of 1 if house has

solar water heater installed

Dummy taking the value of 1 if respondent

stated their house is kept warm

$0.01 \quad 0.08$

$0.97 \quad 0.15$

Answer to the Likert scale question "how

1.05 often do you put on more clothes when they feel cold rather than turn the heating on or turning it up". Different parametrization used. See text and following Tables

Whether the household members believe that UK will be affected by climate change in the next 30 years. Different parametrization used. See text and following Tables

Whether household member's actions are influenced by the need to reduce carbon footprint. Different parametrization used. See text and following Tables

Whether household member believe

environmental protection has high priority.

Different parametrization used. See text and following Tables

Whether household member believe that being environmentalists do not take too much time or effort. Different parametrization used. See text and following Tables

Whether household member is environmentally friendly. Different parametrization used. See text and following Tables

$\begin{array}{ll}0.01 & 0.11 \\ 0.03 & 0.16 \\ 0.1 & 0.31 \\ 0.05 & 0.22 \\ 0.03 & 0.16 \\ 0.05 & 0.21 \\ 0.01 & 0.13 \\ & \\ 0.03 & 0.17 \\ 0.02 & 0.14 \\ 0.01 & 0.11 \\ 0.03 & 0.16 \\ 0.01 & 0.13 \\ 0.02 & 0.13\end{array}$


R. of York \&

$0.02 \quad 0.13$

Humberside

Tyne \& Wear

$0.01 \quad 0.11$

R. of North

$0.02 \quad 0.14$

Wales

$0.17 \quad 0.38$

Scotland

$0.18 \quad 0.38$

Northern Ireland

$0.15 \quad 0.35$ 
Table 2: Correlations between Environmental Variables

\begin{tabular}{|l|l|l|l|l|l|l|}
\hline & $\begin{array}{l}\text { UK } \\
\text { Affected } \\
\text { by CC }\end{array}$ & $\begin{array}{l}\text { Influenced } \\
\text { by CO2 }\end{array}$ & $\begin{array}{l}\text { Environ- } \\
\text { ment } \\
\text { Priority }\end{array}$ & $\begin{array}{l}\text { Time to } \\
\text { be } \\
\text { Environ- } \\
\text { mental }\end{array}$ & $\begin{array}{l}\text { Environ- } \\
\text { ment } \\
\text { Friendly }\end{array}$ & $\begin{array}{l}\text { Add } \\
\text { Layers }\end{array}$ \\
\hline UK Affected by CC & 1 & & & & & \\
\hline Influenced by CO2 & 0.21 & 1 & & & & \\
\hline Environment Priority & 0.21 & 0.31 & 1 & & & \\
\hline $\begin{array}{l}\text { Time to be } \\
\text { Environmental }\end{array}$ & 0.13 & 0.2 & 0.44 & 1 & & \\
\hline $\begin{array}{l}\text { Environment } \\
\text { Friendly }\end{array}$ & 0.1 & 0.3 & 0.31 & 0.27 & 1 & \\
\hline Add Layers & 0.06 & 0.14 & 0.13 & 0.13 & 0.18 & 1 \\
\hline
\end{tabular}


Table 3: Regression Results

\begin{tabular}{|c|c|c|c|}
\hline Dependant Variable & $\begin{array}{l}\text { Ln Heat } \\
\text { Expenditure per } \\
\text { Room } \\
\text { Coefficient (S.E.) }\end{array}$ & $\begin{array}{l}\text { Ln Heat } \\
\text { Expenditure per } \\
\text { Room } \\
\text { Coefficient (S.E.) }\end{array}$ & $\begin{array}{l}\text { Ln Heat } \\
\text { Expenditure per } \\
\text { Room } \\
\text { Coefficient (S.E.) }\end{array}$ \\
\hline Gas & $-0.54 * * *(0.05)$ & $-0.54 * * *(0.05)$ & $-0.54 * * *(0.05)$ \\
\hline Oil & $-0.29 * * *(0.06)$ & $-0.29 * * *(0.06)$ & $-0.29 * * *(0.06)$ \\
\hline Number of Rooms & $-0.55 * * *(0.06)$ & $-0.55^{* * *}(0.07)$ & $-0.55 * * * \quad(0.06)$ \\
\hline Owner Occupied & $0.17 * * *(0.03)$ & $0.17 * * *(0.03)$ & $0.17 * * *(0.03)$ \\
\hline Household Size & $0.23 * * *(0.07)$ & $0.25 * * *(0.06)$ & $0.24 * * *(0.07)$ \\
\hline Income & $0.08 * * *(0.02)$ & $0.08 * * *(0.02)$ & $0.09 * * *(0.03)$ \\
\hline Age & $0.02 * * *(4.6 \mathrm{E}-3)$ & $0.02 * * *(4.6 \mathrm{E}-3)$ & $0.02 * * * \quad(4.6 \mathrm{E}-3)$ \\
\hline Age Squared & $\begin{array}{l}-1.5 \mathrm{E}-4 * * *(4.1 \mathrm{E}- \\
5)\end{array}$ & $\begin{array}{l}-1.5 \mathrm{E}-4 * * *(4.1 \mathrm{E}- \\
5)\end{array}$ & $\begin{array}{l}-1.5 \mathrm{E}-4 * * *(4.1 \mathrm{E}- \\
5)\end{array}$ \\
\hline Number of Children & $0.01(0.04)$ & $0.01(0.04)$ & $0.01(0.03)$ \\
\hline Above A Level Degree & $0.04 *(0.03)$ & $0.03(0.02)$ & $0.04(0.03)$ \\
\hline Not Employed & $0.05(0.03)$ & $0.05(0.03)$ & $0.05(0.03)$ \\
\hline Solar Water Heater & $-0.08(0.08)$ & $-0.08(0.08)$ & $-0.08(0.08)$ \\
\hline Keep House Warm & $0.15(0.12)$ & $0.15(0.12)$ & $0.15(0.12)$ \\
\hline UK Affected by CC & $0.07 \quad(0.05)$ & $0.05(0.03)$ & $0.04(0.03)$ \\
\hline Influenced by $\mathrm{CO} 2$ & $-0.15^{* *} \quad(0.07)$ & $-0.04(0.03)$ & $-0.03 *(0.02)$ \\
\hline Environment Priority & $-0.01 \quad(0.06)$ & $0.02(0.02)$ & 7.2E-4 (0.01) \\
\hline Time to be Environmental & $-0.12 * \quad(0.06)$ & $-0.06 *(0.03)$ & $-0.03 *(0.02)$ \\
\hline Environment Friendly & $0.15^{*}(0.09)$ & $0.01(0.02)$ & $0.03 \quad(0.02)$ \\
\hline Add Layers & $-0.11 * * *(0.04)$ & $-0.07 * *(0.02)$ & $-0.03 * *(0.01)$ \\
\hline $\begin{array}{l}\text { Environmental Question } \\
\text { Specification }\end{array}$ & $\begin{array}{l}\text { Log of Average } \\
\text { Score }\end{array}$ & $\begin{array}{l}\text { Dummies for } \\
\text { above/below } \\
\text { threshold }\end{array}$ & Average Score \\
\hline Building Type Dummies & Yes & Yes & Yes \\
\hline Region Dummies & Yes & Yes & Yes \\
\hline $\begin{array}{l}\text { Builidng Quality } \\
\text { Dummies }\end{array}$ & Yes & Yes & Yes \\
\hline
\end{tabular}

Standard Errors corrected for Heteroskedasticity \& Region Serial Correlation $*, * *, * * *$ indicate $10 \%, 5 \%$ and $1 \%$ statistical significance 
Table 4: Interaction regression models

\begin{tabular}{|c|c|c|}
\hline Dependant Variable & $\begin{array}{l}\text { Ln Heat } \\
\text { Expenditure } \\
\text { per Room } \\
\text { Coefficient }\end{array}$ & $\begin{array}{l}\text { Ln Heat } \\
\text { Expenditure } \\
\text { per Room } \\
\text { Coefficient }\end{array}$ \\
\hline Varıables & $\begin{array}{l}\text { Coefficient } \\
\text { (S.E.) }\end{array}$ & (S.E.) \\
\hline UK Affected by CC & $\begin{array}{l}0.55 \\
(0.97)\end{array}$ & $\begin{array}{l}0.10 \\
(0.12)\end{array}$ \\
\hline Influenced by $\mathrm{CO} 2$ & $\begin{array}{l}-0.20 \\
(0.43)\end{array}$ & $\begin{array}{l}-0.31 * * \\
(0.14)\end{array}$ \\
\hline Environment Priority & $\begin{array}{l}-0.02 \\
(0.43)\end{array}$ & $\begin{array}{l}0.02 \\
(0.08)\end{array}$ \\
\hline $\begin{array}{l}\text { Time to be } \\
\text { Environmental }\end{array}$ & $\begin{array}{l}0.02 \\
(0.54)\end{array}$ & $\begin{array}{l}-0.05 \\
(0.09)\end{array}$ \\
\hline Environment Friendly & $\begin{array}{l}-0.10 \\
(0.55)\end{array}$ & $\begin{array}{l}0.12 \\
(0.17)\end{array}$ \\
\hline Add Layers & $\begin{array}{l}0.04 \\
(0.03)\end{array}$ & $\begin{array}{l}-0.16^{* *} \\
(0.06)\end{array}$ \\
\hline $\begin{array}{l}\text { UK Affected by CC } \\
\text { Income Interaction }\end{array}$ & $\begin{array}{l}-0.05 \\
(0.10)\end{array}$ & $\begin{array}{l}-0.06 \\
(0.12)\end{array}$ \\
\hline $\begin{array}{l}\text { Influenced by } \mathrm{CO} 2 \\
\text { Income Interaction }\end{array}$ & $\begin{array}{l}0.01 \\
(0.04)\end{array}$ & $\begin{array}{l}0.25 \\
(0.23)\end{array}$ \\
\hline $\begin{array}{l}\text { Environment Priority } \\
\text { Income Interaction } \\
\text { Time to be } \\
\text { Environmental Income } \\
\text { Interaction }\end{array}$ & $\begin{array}{l}0.01 \\
(0.04) \\
-0.01 \\
(0.05)\end{array}$ & $\begin{array}{l}0.10 \\
(0.16) \\
-0.10 \\
(0.12)\end{array}$ \\
\hline $\begin{array}{l}\text { Environment Friendly } \\
\text { Income Interaction } \\
\text { Add Layers Income } \\
\text { Interaction }\end{array}$ & $\begin{array}{l}0.01 \\
(0.05) \\
-0.01 \\
(0.03)\end{array}$ & $\begin{array}{l}-0.34 \\
(0.21) \\
0.02 \\
(0.10)\end{array}$ \\
\hline $\begin{array}{l}\text { Environmental } \\
\text { Question Specification }\end{array}$ & $\begin{array}{l}\text { Dummies for } \\
\text { above/below } \\
\text { threshold }\end{array}$ & $\begin{array}{l}\text { Log of } \\
\text { Average Score }\end{array}$ \\
\hline Income Specification & Linear & $\begin{array}{l}\text { Top 25\% } \\
\text { Dummy }\end{array}$ \\
\hline $\begin{array}{l}\text { F-test for all } \\
\text { interactions equal zero }\end{array}$ & $\begin{array}{l}0.22 \\
(\mathrm{P}=0.96)\end{array}$ & $\begin{array}{l}1.92 \\
(\mathrm{P}=0.13)\end{array}$ \\
\hline
\end{tabular}

Other Controls not shown for Brevity

Standard Errors corrected for Heteroskedasticity \& Region Serial Correlation

$*, * *, * * *$ indicate $10 \%, 5 \%$ and $1 \%$ statistical significance 